는

\title{
Benefits of physical therapy in the quality of life of mouth breathing children: Literature review
}

\author{
Natália B. M. de França, ${ }_{1}^{1}$ Fátima S. Ferreira, ${ }^{1}$ Rubens A. Lima, ${ }^{1}$ Juliana R. Ferreira, ${ }^{1}$ Késsia N. A. Sales ${ }^{2 *}$
}

\begin{abstract}
Introduction: The correct breathing process is through the nasal route, since it provides that the air during aspiration is filtered, humidified and heated, thus conditioning the lungs for gas exchange to occur. Allergic processes or other forms of affections can lead to the obstruction of the passage of air through the nose, leading the body to make an alternative adaptation for the passage of air to occur through the mouth. A person who uses the mouth to breathe is called a mouth breather. Once this adaptive process occurs, as a way to compensate for this alternative airway, the body promotes a series of alterations in several segments of the body, such as changes in the postural, respiratory, behavioral and stomatognathic systems. Several techniques are used to treat the musculoskeletal dysfunctions presented by mouth breathers. Objective: to analyze how physiotherapy can contribute to the improvement of the quality of life of mouth breathing children and to find out which are the most effective treatments. Methods: a search of data in the literature was carried out by consulting the following electronic databases: Scielo, Bireme, Pub Med, Lilacs Google Scholar, as well as specialized books in the field. We excluded articles published before the year 2000. Result: Among the analyzed articles, we perceive that the treatment of mouth breathers occurs in a multidisciplinary way, since it presents changes that encompass several body and systemic segments. Among the professionals involved in the rehabilitation process, we highlight the role of physiotherapists. Conclusion: the physiotherapist is qualified to intervene in this pathology, with expertise in evaluation and establishment of the best treatment program, with physiotherapeutic conduits, allowing an improvement in respiratory patterns.
\end{abstract}

Keywords: Mouth breathing children; Physiotherapy; Postural evaluation; Treatment.

\section{Resumo}

Benefícios da fisioterapia na qualidade de vida de crianças respiradoras orais: Revisão de Literatura

Introdução: O processo de respiração correto é através da via nasal, pois proporciona que o ar, durante a inspiração, seja filtrado, umidificado e aquecido, e assim condicionado nos pulmões para que as trocas gasosas ocorram. Processos alérgicos ou outras formas de afecções podem levar à obstrução da passagem de ar pelo nariz; dessa forma, o organismo

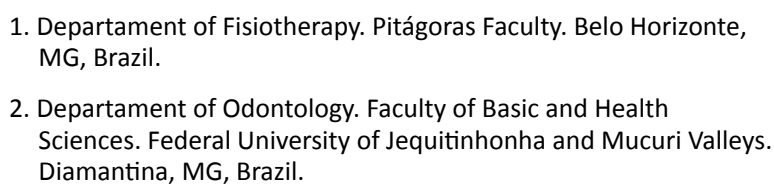

1. Departament of Fisiotherapy. Pitágoras Faculty. Belo Horizonte, MG, Brazil.

2. Departament of Odontology. Faculty of Basic and Health Sciences. Federal University of Jequitinhonha and Mucuri Valleys. Diamantina, MG, Brazil.

*Corresponding address:

Rua da Glória, 157

Diamantina, MG, Brasil.

CEP: 39100-000.

E-mail: sales.kessia@gmail.com

BJHBS, Rio de Janeiro, 2019;18(1):55-63

Recebido em 11/02/2019. Aprovado em 06/06/2019.

realiza uma adaptação alternativa para a passagem do ar que será via oral. O indivíduo que utiliza a boca para respirar é denominado respirador oral (RO). Uma vez realizado esse processo adaptativo, o organismo, como forma de compensar essa via de passagem do ar alternativa, promove uma série de alterações em vários segmentos do corpo, como, por exemplo: alterações posturais, respiratórias, comportamentais e no sistema estomatognático. Existem várias técnicas para tratar as disfunções musculoesqueléticas apresentadas pelo RO. Objetivo: Analisar como a fisioterapia pode contribuir para a melhora da qualidade de vida de crianças respiradoras orais e quais são os tratamentos mais eficazes. Métodos: Foi realizada uma busca de dados na literatura por meio de consulta em bases de dados eletrônicas: Scielo, Bireme, PubMed, Lilacs Google Acadêmico, assim como em livros especializados na área. Foram excluídos artigos publicados antes de 2000. Resultado: Dentre os artigos analisados, percebe-se que o tratamento do RO se dá de forma multidisciplinar, pois ele apresenta alterações que abrangem vários segmentos corporais e sistêmicos. Dentre os profissionais envolvidos no processo de reabilitação, destacamos o fisioterapeuta. Conclusão: O fisioterapeuta é habilitado para intervir na patologia, com expertise para avaliar e estabelecer o melhor programa de tratamento, com condutas fisioterapêuticas que possibilitem uma melhora do padrão respiratório.

Descritores: Respiração oral; Fisioterapia; Tratamento; Avaliação postural. 


\section{Review article}

\section{Resumen}

Beneficios de la fisioterapia en la calidad de vida de los niños respiradores orales: Revisión de literatura

Introducción: El proceso de respiración correcto es a través de la vía nasal, pues proporciona que el aire durante la inspiración sea filtrado, humidificado y calentado, así, condicionado los pulmones para que los intercambios gaseosos ocurran. Los procesos alérgicos u otras formas de afecciones pueden llevar la obstrucción del paso de aire por la nariz, de tal forma el organismo realiza una adaptación alternativa para el paso del aire que será vía oral. El individuo que utiliza la boca para respirar es denominado Respirador Oral (RO). Una vez realizado este proceso adaptativo el organismo, como forma de compensar esa vía de paso del aire alternativa promueve una serie de alteraciones en varios segmentos del cuerpo, como por ejemplo: alteraciones posturales, respiratorias, comportamentales y en el sistema estomatognático. Existen varias técnicas para tratar las disfunciones musculoesqueléticas presentadas por el RO. Objetivo: analizar cómo la fisioterapia puede contribuir a la mejora de la calidad de vida de esos niños respiradores orales y cuáles son los tratamientos más eficaces. Métodos: se realizó una búsqueda de datos en la literatura por medio de consulta en las bases de datos electrónicos: Scielo, Bireme, Pub Med, Lilacs Google Académico y libros especializados en el área. Se excluyeron artículos publicados anteriormente al año 2000. Resultado: Entre los artículos analizados se percibe que el tratamiento del RO se da de forma multidisciplinaria, pues él presenta alteraciones que abarca varios segmentos corporales y sistémicos. Entre los profesionales involucrados en el proceso de rehabilitación, destacamos el fisioterapeuta. Conclusión: el fisioterapeuta está habilitado para intervenir en la patología, con experiencia en la evaluación y establecer el mejor programa de tratamiento, con conductas fisioterapéuticas, que posibiliten una mejora del patrón respiratorio.

Palabras clave: Respiración oral; Terapia física; Tratamiento; Evaluación postural.

\section{Introduction}

Nasal breathing contributes to adequate facial growth and to the correct development of the jaws, mandibular and neuromuscular postures. Humans are primarily nasal breathers. However, alterations can occur in the upper airways and modify this respiratory pattern, leading to mouth breathing. Oral Breathing Syndrome (OBS) is characterized by the replacement of the nasal physiological respiratory pattern by mouth breathing., ${ }^{1,2}$

OBS is a multi-factor current that leads to complete or incomplete nasal obstruction, which can be unilateral or bilateral. This disharmony in breathing causes important impairments both to cognitive aspects and to various organs and structures of the body. ${ }^{3}$

Physical therapy acts on postural changes, setting goals and treatment according to the patient's diagnosis, aiming at the individual's physical and mental health. ${ }^{1}$

The present study is a literature review whose objective is to verify the effectiveness of treatments offered by physical therapy and to analyze how these interventions can promote improvements in the quality of life of mouth breathing children.

\section{Literature review}

The respiratory process

Normal breathing is performed by the nose with the lips closed and without "swallowing air" and aims to supply oxygen to the tissues and remove carbon dioxide. $^{4}$

According to Guyton and Hall (2006), ${ }^{5}$ the most obvious effect of birth in the baby is the loss of placental attachment to the mother and thus the loss of her means of metabolic support. One of the most important immediate adjustments needed is for the baby to start breathing. They also say that, after normal birth from a mother who has not been depressed with anesthetics, the child begins to breathe within seconds and reaches a normal breathing rate in less than a minute after birth. The promptness with which the fetus begins to breathe indicates that respiration is initiated by sudden exposure to the outside world, probably resulting from a mildly asphyxiated state incident to the process of birth, but also from two sensory impulses originating in suddenly cooled skin. ${ }^{5}$

Nasal breathing is associated with normal functions of chewing, swallowing, tongue and lip postures, as well as providing correct muscle action that stimulates proper facial growth and bone development. ${ }^{6}$

The respiratory system is a set of tubular and alveolar organs located in the head, neck and thoracic cavity, which is responsible for breathing, i.e. gas exchanges between the organism and the environment. Air enters by suction and circulates through the nasal cavity, pharynx, larynx, trachea and bronchi before 
reaching the lung. The integrity of these structures is critical to allow efficient breathing.

The outer nose, as well as the outer ear, consists mainly of cartilage covered by skin. However, its proximal portion contains bone covered by skin. It is composed of bone and cartilage. The floor of the nose consists of the hard palate and the soft palate, which forms the roof of the mouth. The roof of the nose is formed by cartilage and the nasal, frontal, ethmoid and sphenoid bones. The frontal and maxillary bones form the nasal bridge. Three bony structures called nasal shells (upper, middle and lower) form the lateral faces of the nose, which increase the surface area of the nose and thus heat, humidify and filter most of the aspirated air. The nose is divided into two chambers (lobes) by a septum. These chambers are lined by a mucous membrane composed of hairs that filter debris and other foreign substances found in the aspirated air. The cribriform plate of the ethmoid bone contains the sensory fibers of the olfactory nerve (cranial nerve I), responsible for the sense of smell. ${ }^{4}$

On average, an adult breathes 7 liters of air per minute, but this can reach up to 100 liters per minute when in intense physical activity. A newborn breathes 40 times per minute, a one-year-old child breathes 24 times per minute and an adult breathes 14 times per minute on average.

The respiratory process is guaranteed primarily by muscle contraction; during aspiration the most important muscle is the diaphragm, which consists of a thin, dome-shaped muscular blade inserted in the lower ribs. It is supplied by phrenic nerves from cervical segments 3, 4 and 5.,7

Physiologically, nasal breathing provides balance to the orofacial musculature, which stimulates the adequate growth and development of the craniofacial complex, favoring the individual's structural harmony. ${ }^{7}$ It directly influences the development of the jaw, posture of the mandible, position of the tongue, rhinopharyngeal air space and maintenance of the physiological cervical curvature. ${ }^{9}$ In addition, it affects the proper functioning of other stomatognathic functions, such as chewing, sucking, swallowing and speaking. ${ }^{10}$

The stomatognathic system (SS) is an anatomically integrated and physiologically coordinated morphofunctional unit characterized by several structures that perform common functions. It is formed by the teeth and the structures that surround them, by the jaws, temporomandibular joints (TJ) and the muscles that are inserted in the mandible, labial and lingual muscles, as well as by the vessels and nerves corresponding to these tissues. ${ }^{8}$ Among the components of the SS, the hard palate is the structure that plays a role in all of its functions. Under normal conditions, it provides solid tongue contact as well as support for rapid and complex movements. ${ }^{11}$

The structures involved in the SS can be classified as static, passive and dynamic (or active). The first are constituted by the dental arches, maxilla and mandible, which are related to each other by the TJ. These structures include the hyoid bone and other cranial bones. The dynamic or active ones are represented by the neuromuscular unit, which mobilizes the static parts. These structures are interconnected to perform the vital (breathing, sucking, chewing, swallowing) and social (phonation and articulation) functions of the organism, which are extremely important for the maintenance of the physical-biological balance of human beings. They form a system with its own characteristics located in the oral cavity and not specialized in any single function. Therefore, changes in any of its parts lead to a general imbalance of the system. ${ }^{12}$

The accessory muscles of aspiration include the scalene muscles, which lift the first two ribs and the sternocleidomastoid (SCM), which elevates the sternum. Also related to the respiratory act are the external intercostal muscles, which connect adjacent ribs and tilt downward and forward. When contracted, the ribs are pulled up and forward to increase the lateral and anteroposterior dimensions of the thorax. They are supplied by intercostal nerves coming from the spinal cord at the same level.

Expiration is usually passive, not depending on muscle contraction, and is caused by the elastic recoil of the lungs and rib cage. Only during forced expiration does contraction of the expiratory muscles occur, of which the abdominal muscles are the most important. ${ }^{5}$

The nose, in addition to being a passive conductor through which air is drawn from the atmosphere, is a highly specialized organ capable of performing three important respiratory functions: humidification, heating of aspired air and protection of the upper airways. ${ }^{12}$ As air passes through the nose, three distinct respiratory functions are performed by the nasal cavities: (1) the air is heated by the extensive surfaces of the shells and septa; (2) the air is almost completely humidified; and (3) the air is partially filtered. These functions are collectively termed the air conditioning 


\section{Review article}

of the upper airways. Other functions found are gas, olfactory and phonatory changes. Gas exchange occurs in the areas where the alveoli, alveolar sacs, alveolar ducts and respiratory bronchioles are located. ${ }^{5}$

In order for nasal breathing to be maintained, the anatomic and functional integrity of the airways must be preserved. However, any factor that leads to obstruction of the upper airways causes the nasal respiratory mode to be replaced partially or totally by the mouth breathing. ${ }^{14}$

Although nasal breathing is beneficial, some individuals, especially children, have difficulty maintaining physiological respiration. ${ }^{4}$

\section{Mouth breathing}

In order for nasal breathing to occur efficiently, the passage of air through the nostrils is necessary. When physiological respiration does not occur, this breathing will occur predominantly through the mouth, that is, mouth breathing. ${ }^{15}$

The physiological aspects of children's breathing can be altered when there are prolonged changes in the respiratory pattern, from nasal to oral. This condition is called OBS when maintained for a period of time equal to or greater than six months. OBS is common in childhood, most usually in schoolchildren. ${ }^{16}$

The individual who, for whatever reason, changes his respiratory pattern from nasal to the mouth, will undergo changes not only in the apparatus involved with breathing but also myofunctional changes that modify the body axis and its dynamics. ${ }^{17}$

OBS is characterized by a change in the physiological pattern of breathing, in which the oral or mixed nasal airway is replaced by functional, structural, postural, biomechanical, occlusal and behavioral disorders. ${ }^{18}$ It is characterized by a set of signs and symptoms that may be present completely or incompletely in those individuals who, for various reasons, replace the correct pattern of nasal breathing. Among these individuals, we highlight functional mouth breathers, who are those that used to present obstructions to nasal breathing, but have been corrected. However, even though the upper tract is completely permeable, they continue to breathe through their mouths. ${ }^{2}$

With the interruption of the physiological process of breathing, we find mouth breathing, a functional adaptation that entails modifications not only to the organs and devices directly involved, but also in the body dynamics as a whole. It is an adaptive function in which the SS can promote structural changes that allow its installation and functionality, impairing the balance between masticatory functions, swallowing, breathing and phonation, a necessary condition for the proper development and normal growth of this system. ${ }^{12}$

Nasal breathing is essential because it stimulates the sensors of the nasal mucosa, by filtering, heating and humidifying the air before reaching the lung and fulfilling its function of hematosis. The flow and reflux of air through the nostrils produce pressure that expands the airways and aerates the pneumatic paranasal cavities. This is why it is one of the main factors for craniofacial growth and development, as well as for the protection of the lower airways. However, if factors such as septal deviation, hypertrophic palatine and pharyngeal tonsils due to allergic processes (rhinitis, sinusitis, bronchitis) and malformations prevent the passage of air through the nasal cavity, there is a change in respiratory mode, which becomes predominantly oral. ${ }^{3}$

Nasal breathing is a physiological function that is necessary for the orofacial structures to maintain and develop healthily. Due to the lack of stimulation of the passage of the airway through the nasal conduit, the pressures and strains that ensure the correction of the maxillary sinuses do not occur. The nostrils turn into narrow nasal clefts with reduced volume and elasticity lowered by disuse, presenting pale nasal mucosa, lack of filtration and warm air during breathing. ${ }^{15}$

The persistence of oral breathing during the child's growth phase may determine a series of morphofunctional changes that are not restricted to the craniofacial region. These alterations include changes in the phonoarticulatory organs, such as hypotrophy, hypotonia and hypofunction of the jaw lift muscles, alteration of the tonus of the lips and cheeks, and anterioration of the tongue. With regard to oral functions, consequences include poor chewing, atypical swallowing, inaccurate speech and a hoarse voice. One finds decreases in smell and taste, halitosis, altered sleep and frequent sinusitis, as well as poor academic and physical performance. The most obvious craniofacial and dental changes are narrow facial dimensions, overjet, open or crossbite. ${ }^{3}$

\section{Etiology and clinical manifestations in Oral Breathing Syndrome}

OBS may be related to genetic factors, inappropriate oral habits and nasal obstruction of varying severity and duration. A child who chronically breathes through the mouth may develop speech disorders, 
facial deformities, incorrect positioning of teeth and inadequate body posture. ${ }^{19}$

There are several etiologies of mouth breathing, such as adenotonsillar hyperplasia; allergic and nonallergic rhinitis; hypertrophy of inferior turbinates; etc., of which allergic rhinitis is one of the most frequent. ${ }^{2}$ According to Bianchinni, et al. (2007) ${ }^{20}$ mouth breathing can be caused by an obstruction of the upper airways or by a habit that causes air to pass through the mouth.

Mouth breathing is a consequence of several basic conditions, including mechanical factors (changes in the nasal septum, adenotonsillar hyperplasias), inflammatory diseases (allergic rhinitis), congenital malformations with craniofacial deformities and tumor lesions. Allergic rhinitis is especially noteworthy, since it affects about 10 to $30 \%$ of the general population and its incidence has been on the rise throughout the world for decades. ${ }^{21}$

\section{Characteristics and positional compensation changes}

The mouth breathing patient has some typical features such as: elongated face; narrow nostrils; lack of facial muscle tone; inadequate lip sealing; drooping eyes; dark circles; shoulder closure; spinal imbalance; small nose with pyramid very enlarged bone; lower hypotonic and hypertonic upper lip; and protrusion of anterior teeth. The lateral orbicularis muscle of the lips is used to perform the lip seal, giving a downward curvature with great prejudice to the mental and paramentonian group, leading the patient to complain of pain in the neck and nape. ${ }^{22}$

Mouth breathing causes inhibition of the nasal afferent, autonomic nerves and trigeminal sympathetic nerves, which act to regulate the depth of breathing and the caliber of the areas. Nasal blockages result in increased resistance and decreased pulmonary compliance, affecting the expansion of the chest by inadequate alveolar ventilation. It has also been shown that the breathing pattern imposed by the mouthpiece simulator implies adaptive postural needs. To facilitate the passage of airflow through the oral cavity, the individual projects the head and extends the neck. In this way, the passage of air through the pharynx is increased, reducing the resistance of the airways. ${ }^{18}$

In addition, mouth breathing can cause damage in several areas, leading individuals to present changes in: craniofacial structure; body posture; facial muscles; occlusion; chewing and swallowing functions; sleep; concentration and attention disorders; in addition to increased incidence of otitis episodes and other middle ear pathologies, which lead to hearing loss. The persistence of alteration of the upper airways causes damage to the ventilatory mechanics, with an imbalance of muscular forces that can produce temporomandibular dysfunctions, thoracic dysfunctions and, consequently, deviations in all postural axes. ${ }^{23}$

OBS induces a number of morphofunctional changes, which are characterized by open mouth, hypotonia of the tongue and intraorbital cyanosis. In addition, mouth breathers can experience nighttime apnea, hypoventilation and abnormal chest growth. In some cases, facial features may be altered, such as an elongated and distended face, parched and parched lips, drooping cheeks, lower hypotonic tongue or between the teeth, dark circles, flaccidity of the entire musculature of the face, dental malocclusion, and narrow and deep palate. Mouth breathers usually prefer to eat open-mouthed, drool on the pillow when sleeping and present changes in their behavior, such as restless sleep, irritability, difficulty in concentrating, restlessness, anxiety and lack of patience. Diminished school performance and low athletic ability are common. ${ }^{6}$

Breathing through the mouth may lead to changes in the respiratory pattern, which presents an increased respiratory rate associated with decreased amplitude and the need to use the accessory musculature involved in aspiration in order to overcome high nasal resistance. ${ }^{24} \mathrm{With}$ regard to orofacial alterations of mouth breathers, the literature cites long and narrow faces; parted lips, with the upper one short and lower one averted; poorly developed jaws; infraorbital cyanosis; decreased orofacial musculature; expressionless face; hypotonia of the tongue; atypical swallowing; and craniofacial malformations. The postural alterations observed include asymmetry of the thorax, anteriorized shoulders, flexed head, forward rotation of the shoulders, forward flexed neck, rectification of the cervical spine, and impaired posture of the lower limbs. ${ }^{25}$ Body changes observed in mouth-breathing children include: poorly positioned head, flaccid abdominal muscles, protruding shoulders and thoracic deformities. The muscular chains represent circuits with continuity of direction and plane, through which the organizing forces of the body are propagated. The orofacial and corporeal muscular chains are functionally interrelated through neuromuscular synergy. ${ }^{3}$ 


\section{Review article}

Normal neuropsychomotor development is characterized by a gradual acquisition of posture control, with the appearance of rectification and balance reactions. The development of these reactions, which are controlled by the central nervous system, allows the individual to maintain the posture and balance of the head, trunk and extremities under normal circumstances. Mouth breathing children need to adapt their posture by anteriorising the head. Thus, a chain of adaptive postural compensations throughout the organism arises, such as shoulders in protrusion, cervical rectification and lumbar hyperlordosis, dorsal hyperkinesis, prominent abdomen, pelvic anteversion, hyperextended knees and pronated feet. ${ }^{3}$ The treatment for OBS is not restricted to a single professional field, but is a multidisciplinary interaction that includes speech therapists, physiotherapists, dentists, otolaryngologists and ophthalmologists. ${ }^{12}$

\section{Physiotherapeutic approach}

Breathing through the mouth causes facial, postural and behavioral changes that worsen the quality of life of the patient. These characteristics lead to a vicious cycle, generating more serious problems and affecting the self-esteem of patients with this syndrome. Due to the changes that mouth breathing can provoke, treatment becomes of paramount importance. A multi-professional team must be engaged in the treatment in order to achieve global patient care. The role of physiotherapy in this team is fundamental, since it reeducates breathing, improves pulmonary ventilation, prevents and corrects thoracic and postural deformities, and re-educates the musculature involved in the alterations that are present. ${ }^{2}$

Within the team of health professionals, the physiotherapist is the one that has the function of preventing and treating such dysfunctions, through the use of therapeutic exercises, as well as manual, mechanical and electrothermophototherapeutic resources. ${ }^{26}$

By changing the tone of the facial muscles, mouth breathing impairs the chewing and swallowing functions, as well as modifying the body posture of the individual, which becomes, over time, a source of pain. In the medium or long term, this can cause damage that is often irrecoverable, such as: chest and posture alterations; and facial changes (muscle and bone), especially during the growth phase. If OBS is not diagnosed and treated at an early stage, postural instability may become degenerative skeletal deformity, leading to serious and profound consequences. Therefore, it is important to study this dysfunction as well as its prevention and treatment in order to ensure the physical and emotional wellbeing of individuals and to give them a better quality of life. ${ }^{26}$

Due to the syndromic nature of mouth breathing, an interdisciplinary approach has been proposed for its diagnosis and treatment. However, the therapeutic approach in this syndrome has been currently directed to orofacial changes through orthodontic and speechlanguage therapy. For complete rehabilitation of these patients, the treatment of postural and respiratory changes by physical therapy should be included. In addition, the intervention of physiotherapy can assist in dental rehabilitation, speech therapy and the involvement of other professionals, allowing more effective therapeutic results and long-term effects in these patients. ${ }^{27}$

Godoy et al. (2000), ${ }_{17}^{17}$ based on OBS evaluation protocols presented by different authors with different backgrounds, considered the information needs of the physiotherapist and produced a proposal for a protocol for the evaluation of mouth breathers, highlighting mainly postural issues.

The patient's history must be described in detail, since this information will be useful in identifying the major complaints, which will be important in drawing up the appropriate treatment. Biometry is important for the evolutionary control of the patient during treatment, especially when the focus of interest is posture. Examination of the TJ assists in the characterization of the face of the mouth breather, in addition to being important for referral to a responsible professional when alterations in the bite and teeth are detected. The evaluation of respiratory conditions is important, since these are interrelated with posture and postural reeducation work. ${ }^{17}$

A study conducted by Held et al. (2008) ${ }^{28}$ evaluated 10 male children with a mean age of $8.5+/-2.78$ years, only 8 of which completed the 18 sessions relevant to the study. The presence of postural alterations was observed in these children. The most frequent abnormalities, corroborating with the literature, corresponded to facial asymmetry (75\%), cervical hyperextension (75\%), shoulder protrusion (100\%), winged scapula (75\%), abdominal protrusion (75\%) and pelvic imbalance (50\%). These postural changes, in turn, lead to a decrease in the shape and performance of respiratory muscles, since they undermine their length-tension relationship. 


\section{Physiotherapeutic treatment}

Early intervention in the mouthpiece is extremely important for successful treatment. Causes and consequences must be distinguished during evaluation. The evaluation should be thorough and contain a detailed postural and oromiofacial evaluation. Based on the findings, it is possible to build the objectives and to draw up proposals for physiotherapeutic treatment, which should be individualized. The treatment should not be performed in isolation, since the participation of a multidisciplinary team is of fundamental importance in improving the quality of care. ${ }^{3}$

The main objective of physical therapy is the re-education of breathing, for which several physiotherapeutic techniques have been used, among which is respiratory biofeedback as a form of intervention, providing the patient with visual information about one or more physiological events correlated with respiration, such as frequency peripheral oxygen saturation, carbon dioxide expired fraction, tidal volume, respiratory flows and movements of the chest and abdomen, which are shown to patients in order to teach them to manipulate these events for their therapeutic benefit, thereby improving their respiratory performance. ${ }^{2}$

The goals of physiotherapy for the treatment of these patients include: improving the quality of life; rebalancing the skeletal muscle system; preventing seizures and improving respiratory control in the presence of acute episodes, thus preventing chest deformities and alterations of the spine; increasing ventilatory capacity; re-educating and raising awareness of diaphragmatic breathing; and correcting global posture. Early physiotherapeutic intervention has a better prognosis when the postural and physiological picture of the mouth breather is still not completely altered, promoting satisfactory results, rebalancing the musculoskeletal system and increasing respiratory capacity.

Regarding the forms of intervention, respiratory kinesiotherapy combined with postural reeducation seeks to restore the balance altered by the syndrome, preparing children and even adults for the practice of sports. ${ }^{26}$

Respiratory kinesiotherapy exercises involve the trunk and limbs and are always associated with activation of the diaphragm, since this is the most important muscle for breathing. The prominent inspiratory movement of the upper thorax influences the thoracoabdominal mechanics, altering the positioning of the diaphragm muscle and decreasing intra-abdominal pressure. The lengthening of the aspiratory muscles facilitates diaphragm dynamics and should preferably be performed during expiration, thus avoiding chest-distending compensations that impair ventilation. Muscle shortening, as well as postural alteration, leads to a loss of strength in the respiratory muscles, since it causes changes in lung volume, generating thoracic deformities, global and trunk modification. ${ }^{26}$

The techniques of Global Posture Reeducation or muscular chains can be used in mouth breathers, where the body works by means of static muscular stretching and dynamic strengthening, following the muscular chain that is causing pain and other disorders. In this method, breathing mobilizes all the muscles of the chest by unlocking them and relaxing the muscles, which improves posture. Other postural correction techniques, such as active global stretching and isostretching, may also be used. ${ }^{26}$

The approach of physiotherapy in OBS should be global and directed both towards the correction of postural deviations and muscular imbalances as well as towards the improvement of the ventilatory function. Among the known and indicated methods for postural motor reeducation is intervention with exercise (Swiss) balls. The goals of treatment with exercise balls are: stabilization of the spine; auto correction of posture; corporal symmetry; proprioceptive training and of corporal perception; relaxation; and training of diaphragmatic breathing. ${ }^{27}$

\section{Discussion}

Corrêa (2005) ${ }^{27}$ evaluated 19 children who had been diagnosed with nasal obstruction, confirmed by endoscopic exams, without other associated pathologies. The objective was to evaluate the effectiveness of a physical therapy intervention program on cervical muscles and body posture in mouth breathing children. Electromyographic and photographic evaluations were performed before and after treatment in order to verify the efficacy of the physiotherapeutic intervention. A significant reduction of electromyographic activity in the muscles evaluated with physical therapy was observed. The treatment also obtained positive results in the correction of the anterior position of the head and scapular abduction, demonstrated by computerized image analysis. The methods used 
to assess the efficacy of physical therapy were safe and reliable when used with adequate care and instrumentation, showing that this intervention was effective in improving the muscle balance and postural patterns of mouth breathing children. The successful treatment of children with mouth breathing depends on the careful evaluation and treatment of its multifactorial causes.

For Marins (2004), ${ }^{1}$ hydrotherapy contributes to the correction of problems in coordination, muscular imbalances and painful conditions. It can be adapted for mouth breathing patients since they present postural and respiratory changes. The therapy through movement called kinesiotherapy has several forms of application, all of which aim at the reorganization of muscle harmony through relaxation, stretching and strengthening and are based on the changes presented by the mouth breather. All alterations should be taken into account. Postural correction activities can be performed in several ways and, in the case of children, an auxiliary play component to facilitate the evolution of therapy is sufficient.

In a case report, Borges et al. (2011) ${ }^{29}$ evaluated a 10 -year-old mouth breathing patient with the objective of describing the clinical case and the physiotherapeutic treatment, allowing a possible improvement in the respiratory condition and postural pattern, as well as changes in the activities of daily life. The purpose of this study was to perform physiotherapeutic care three times a week, with each session lasting 60 minutes, for a period of two months, totaling 20 sessions. The techniques used in this study were based on the principles of RPG and manual therapy. After two months of treatment, a reevaluation was performed and it was noticed that respiratory exercises had contributed to the reduction of dyspnea on exertion. In this study, an improvement was found in the quality of life of an asthmatic patient after treatment.

Ferreira et al. (2012) ${ }^{30}$ studied 10 mouth breathing children who underwent a program of 20 sessions of respiratory muscle re-education, through diaphragmatic stimulation and manual stretching of the accessory muscles of inspiration, and exercises for correction postural on the Swiss ball. This approach produced positive effects on ventilatory parameters and had a favorable effect on thoracic mobility. After ten sessions, an increase in respiratory capacity ( $\mathrm{p}=$ 0.05) occurred. Between the initial evaluations and after 20 sessions, an increase in maximal inspiratory pressure $(\mathrm{p}<0.01)$ was observed.

The study conducted by Correa and Bérzin (2007) $)^{31}$ included 19 children with oral breathing syndrome, who were evaluated by surface electromyography of the cervical muscles (SCM, suboccipital and trapezius descending fibers) before and after a physical therapy program, which included posture exercises associated with diaphragmatic breathing with manual stimulation on the Swiss ball. After 12 sessions, a significant reduction in the action of the analyzed muscles was found, restoring muscle imbalances and postural disturbances measured through surface electromyographic activity.Short-term improvements were seen on anterior head and shoulders, unilateral shoulder elevation, and scapular abduction.

\section{Conclusion}

The studies reported suggest that mouth breathing is not physiological, and can trigger numerous changes in the child, including those of a musculoskeletal, emotional and psychosocial nature. In light of the complexity of alterations involving patients with this dysfunction, an intervention by a multiprofessional team is required. Physical therapy has an important role to play in the treatment of OBS, and early intervention, when the postural and physiological conditions have not been completely altered, promotes very satisfactory results and has a favorable prognosis. The intervention aims to rebalance the musculoskeletal system and increase respiratory capacity, thus improving the quality of life of these patients.

Physiotherapy has many therapeutic techniques to rehabilitate the mouth breather, so professionals in this field must be aware of the changes arising from mouth breathing, as well as have the ability and dedication to propose the most appropriate treatment.

We conclude that no single specific technique must be used, since each type with its particularities can be beneficial when correctly applied, thus promoting a better quality of life. However, little scientific evidence exists of which technique is most effective, and further studies are needed on the subject for a better validation of physiotherapy in OBS in order to prove the benefits of rehabilitation in this population. 
Natália B. M. de França e cols. • Benefits of physical therapy in the quality of life of mouth breathing children

\section{References}

1. Marins SR. Síndrome do Respirador Bucal e modificações posturais em crianças e adolescentes: a importância da Fisioterapia na equipe interdisciplinar. Fisioter Mov. 2001;14(1):45-52.

2. Barbiero EF, Vanderlei LCM, Nascimento PC. A síndrome do respirador bucal: uma revisão de literatura. Iniciac. Cient. CESUMAR. 2002;4(2):125-130.

3. Basso DBA, Souza JA, Pasinato F, et al. Estudo da postura corporal em crianças com respiração predominantemente oral e escolares em geral. Saúde (Sta Maria). 2009;35(1):21-27.

4. Magge D. Avaliação Musculoesquelética. 5. ed. São Paulo: Manole; 2010. paginas

5. Guyton AC, Hall JE. Tratado de Fisiologia Médica. 11. ed. Rio de Janeiro: Saunders Elsevier; 2006. paginas

6. Felcar JM, Bueno IR, Massan ACS, et al. Prevalência de respiradores bucais em crianças de idade escolar. Cien Saude Colet. 2010 Mar;15(2):437-44.

7. West JB. Fisiologia Respiratória: princípios básicos. 8. ed. Porto Alegre: Artmed; 2000. paginas

8. Marchesan IQ. Fundamentos em fonoaudiologia: aspectos clínicos da motricidade oral. 2. ed. Rio de Janeiro: Guanabara Koogan; 2005. paginas

9. Lessa FCR, Enoki C, Feres MFN, et al. Influência do padrão respiratório na morfologia craniofacial. Rev Bras de Otorrinolaringol, $2005 \mathrm{Mar} / \mathrm{Abr} ; 71(2): 156-60$.

10. Costa TLS, Silva HJ, Cunha DA. Análise qualitativa interobservadores e avaliação morfométrica do palato duro. Rev CEFAC. 2005 Jul/Set;7(3):326-35.

11. Felicio, CM. Fonoaudiologia aplicada a casos odontológicos, motricidade oral e audiologia. 1. ed. São Paulo: Pancast; 1999. paginas

12. Machado PG, Mezzamo CL, Badaró AFV. A postura corporal e as funções estomatognáticas em crianças respiradoras orais: uma revisão de literatura. Rev CEFAC. 2012;14(3):553-65.

13. Gallo J, Campiotto AR. Terapia miofuncional orofacial em crianças respiradoras orais. Rev CEFAC. 2009;11(suppl 3):30510.

14. Krakauer LH, Guilherme A. The relationship between mouth breathing and postural alterations in children: a descriptive analysis. Int J Orofacial Myology. 2000 Nov;26:13-23.

15. Cunha RA, Cunha DA, Bezerra LA, et al. Aeração nasal e força muscular respiratória em crianças respiradoras orais. Rev CEFAC. 2015 set/out;17(5):1432-144.

16. Conti PBM, Sakano E, Ribeiro MA, et al. Assessment of the body posture of mouth-breathing children and adolescents. J Pediatr (Rio J). 2011 Jul-Aug;87(4):357-63. doi: 10.2223/ JPED.2102. Epub 2011 Jul 18.
17. Godoy P, Niitsuma LEM, Caromano FA. Avaliação funcional fisioterapêutica do respirador bucal. Arq Ciênc Saúde Unipar. 2000;4(2):111-120.

18. Okuro RT, Morcillo AM, Sakano E, et al. Exercise capacity, respiratory mechanics and posture in mouth breathers. Braz. Journal Otohinolaryngol. 2011 Set/Out;77(5):656-62.

19. Abreu RR, Rocha RL, Lamounier JA, et al. Etiology, clinical manifestations and concurrent findings in mouth-breathing children. Jornal de Pediatria. 2008;84(6):529-35.

20. Bianchini AP, Guedes ZCF, Vieira MM. Estudo da relação entre a respiração oral e o tipo facial. Rev Bras Otorrinolaringol. 2007 jun/Ago;73(4):500-5.

21. Barros JRC, Becker HMG, Pinto JA. Evaluation of atopy among mouth-breathing pediatric patients referred for treatment to a tertiary care Center. Jornal de Pediatria. 2006;82(6):458-64.

22. Menezes VA, Tavares RLO, Granville-Garcia AF. Síndrome da respiração oral: alterações clinicas e comportamentais. Arq Odontologia. 2009 Jul/Set;45(3):160-5.

23. Motta LJ, Martins MD, Fernandes KPS, et al. Relação da postura cervical e oclusão dentária em crianças respiradoras orais. Rev CEFAC. 2009;11(3):298-304.

24. Brant TCS, Mancini MC, Becker HMG, et al. Padrão respiratório e movimento toracoabdominal de crianças respiradoras orais. Rev Bras Fisioter. 2008 Nov/Dez;12(6):495501.

25. Campanha SMA, Freire LMS, Fontes MJF. O impacto da asma, da rinite alérgica e da respiração oral na qualidade de vida de crianças e adolescentes. Rev CEFAC. 2008 Out/Dez;10(4):513-9.

26. Brech CG, Augusto CD, Ferrero P, et al. Alterações posturais e tratamento fisioterapêutico em respiradores bucais: revisão de literatura. Acta ORL. 2009;27(2):80-4.

27. Corrêa ECR. Eficácia da intervenção fisioterapêutica nos músculos cervicais e na postura corporal de crianças respiradoras bucais: avaliação eletromiográfica e análise fotográfica computadorizada [Doutor]. Faculdade de Odontologia de Piracicaba, Universidade Estadual de Campinas; 2005. paginas

28. Held PA, Castro WM, Silva TLP, et al. Treinamento muscular e da respiração nasal em crianças respiradoras orais. Fisioterapia em Movimento. 2008;21(4):119-27.

29. Borges JBC, Oliveira JP, Barbosa IMP, et al. Tratamento fisioterapêutico na síndrome do respirador bucal. Pediatria moderna. 2011;47(3):98-104.

30. Ferreira FS, Weber P, Corrêa ECR, et al. Efeito da fisioterapia sobre os parâmetros ventilatórios e a dinâmica tóracoabdominal de crianças respiradoras bucais. Fisioter. Pesqui. 2012;19(1):8-13.

31. Corrêa ECR, Bérzin F. Efficacy of physical therapy on cervical muscle activity and on body posture in school-age mouth breathing children. Int. J. Pediatr. Otorhinolaryngol. 2008;71(10):1527-35. 